\title{
Spectrophotometric Characterization of Behavior and the Predominant Species of Flavonoids in Physiological Buffer: Determination of Solubility, Lipophilicity and Anticancer Efficacy
}

\author{
Montree Tungjai ${ }^{1}$, Wilart Poompimon ${ }^{2}$, Chatchanok Loetchutinat ${ }^{1}$, Suchart Kothan ${ }^{1}$, \\ Nathupakorn Dechsupa ${ }^{1}$ and Samlee Mankhetkorn ${ }^{*}, 1$
}

${ }^{1}$ Laboratory of Physical Chemistry, Molecular and Cellular Biology and Center of Excellence for Molecular Imaging,
Department of Radiologic Technology, Faculty of Associated Medical Sciences, Chiang Mai University, Chiang Mai
50200, Thailand
${ }^{2}$ Laboratory of Natural Products, Department of Chemistry, Faculty of Science, Lampang Rajabhat University,
Lampang, Thailand

\begin{abstract}
The objectives of this study were to investigate the behavior of flavonoids in an aqueous physiological buffer and to determine the structural and functional group substitution which is responsible for their anticancer action. The deprotonated anionic form of 7 flavonoids can easily be determined using spectrophotometry, and owing to its charged state, is highly soluble in aqueous physiological buffer and is not prone to aggregation. The protonated form of these 7 flavonoids is much less soluble and tends to aggregate following precipitation. For all flavonoids studied except catechin and $5,5^{\prime}$-dihydroxy-6,7,3',4'-tetramethoxyflavone, it was possible to determine the rates of deprotonation; pKa value of eriodictyol, apigenin, kaempferol, quercetin, WP 279, and WP 283 was equal to 7.00, 8.72, 7.86, 8.30, 7.70 and 9.90, respectively. The methoxyl group substitutions in place of hydrogen atoms and/or hydroxyl groups at various positions of carbon atoms in ring A, B and C particularly WP 283 resulted in an increase in the solubility, lipophilicity, and specifically its anticancer efficacy (by 60 -fold). The neutral forms of flavonoids are predominantly active molecules and the active sites responsible for anticancer activity are found in ring $\mathrm{A}$ and $\mathrm{C}$, especially $\mathrm{C} 4=\mathrm{O}, \mathrm{C} 5-\mathrm{OH}$ and $\mathrm{C} 2=\mathrm{C} 3$.
\end{abstract}

Keywords: Aggregation, flavonoid, anticancer action, multidrug-resistance, rate of deprotonation, lipophilicity.

\section{INTRODUCTION}

Compounds based on a flavonoid ring structure are emerging as a potentially important new class of pharmaceutical compounds with a broad range of biological activities, most prominent of which are their potential role as antioxidant and apoptosis-inducing agents [1-4]. The dual activities of the antioxidant and the apoptosis-inducing properties of some flavonoids provide evidence of anticancer molecules and attempts are made to develop new therapeutics based on dietary isoflavones or novel isoflavonoid structures in cancer treatment $[5,6]$. Many research groups have reported the flavonoid effects on cancer cells and potential for therapy of various kinds of cancers in the future. With the available in vitro and in vivo data, it is likely that flavonoids will move into the clinical arena as therapeutic or preventive tools for cancer [1, 5-12].

Despite the great interest in these compounds over recent years, there is little data dealing with their solubility, chemical evolutions and predominant form in aqueous physiological solution. These parameters directly contribute to free neutral flavonoids available to mediate specific interaction of molecules in cells, supporting the hypothesis that the degree of cytotoxicity of these molecules should be dependent on

\footnotetext{
*Address correspondence to this author at the Laboratory of Physical Chemistry, Molecular and Cellular Biology, Center of Excellence for Molecular Imaging, Department of Radiologic Technology, Faculty of Associated Medical Sciences, Chiang Mai University, Chiang Mai 50200, Thailand; Tel: 6653-949305; Fax: 6653-949207; E-mail: samlee@chiangmai.ac.th
}

the high concentration of molecules at their intracellular targets. In order to increase the intracellular target concentration of flavonoids, at least two parameters should be taken into account. One is the molar fraction of free monomer neutral flavonoid in the extracellular medium represented by the solubility of molecules. The other parameter is the diffusion rate constant that affected by the properties of cells, the diffusing molecule and the surrounding solutions. If we consider the diffusion of a molecule in the same cell types, the diffusion rate constant is predominantly governed by the lipophilicity $(\log \mathrm{P})$ of the molecule. A recent study reported that the solubility of flavonoids depends on temperature [13], nature of the solvents and of the $\mathrm{pH}[14,15]$. For example in an aqueous solution at $\mathrm{pH} 1.5$, the solubility of hesperetin and naringenin are $0.2 \mu \mathrm{M}$ and $0.1 \mu \mathrm{M}$, respectively, whereas at $\mathrm{pH} \mathrm{8}$, their solubility increases 4-fold [13]. Indeed, the concentration ranges of flavonoid solutions were limited due to their restricted solubility: quercetin $(0.1-30 \mu \mathrm{M})$, rutin $(0.1$ $-200 \mu \mathrm{M})$ and kaempferol $(0.1-30 \mu \mathrm{M})[16]$. With the objective being to establish a rational approach and to explain the solubility of flavonoids, several studies have been devoted to developing a correlation between the thermodynamic and structural properties and the solubility of these compounds. For instance, it was shown that the solubility of compounds can be correlated to their thermodynamic properties [17] that were affected by the ability of compounds to form hydrogen bonds with the surrounding solvent [18].

The flavonoids (C6-C3-C6) are good chromophores that absorb light between $200 \mathrm{~nm}$ to $400 \mathrm{~nm}$. Regarding to the 
light absorption property, the chemical evolutions and predominant species of flavonoid molecules in an aqueous solution can be studied by using the spectrophotometric method. Moreover, the deprotonation of flavonoids in a physiological solution can be facilitated by a charge delocalization in the anion to the C4-keto moiety [19] that has specific electronic absorption properties which are spectrophotometrically characterized as described by Sauerwald et al. [20] and Dangles et al. [21].

It is of prime importance to determine the relationship among the chemical structure, their behavior (in terms of lipophilicity and solubility) in physiological buffer solution, and the anticancer efficacy of flavonoids. Therefore, in this study, 7 flavonoids (for chemical structure see Fig. (1)) were selected and their molecular physical properties, such as aggregation, deprotonation rates and lipophilicity, were vigorously studied. The hydroxyl or methoxyl group substitutions at various positions of carbon atoms in ring $\mathrm{A}, \mathrm{B}$ and $\mathrm{C}$, particularly for WP 283, resulted in a protection of a neutral form to undergo an aggregation or increase in its solubility and its $\log \mathrm{P}$ value, thus increasing its anticancer efficacy by 60 -fold. The predominant active molecules should be the neutral form and the active site for anticancer activity of molecules are found in ring $\mathrm{A}$ and $\mathrm{C}$, specifically $\mathrm{C} 4=\mathrm{O}, \mathrm{C} 5-$ $\mathrm{OH}$ and $\mathrm{C} 2=\mathrm{C} 3$.

\section{MATERIALS AND METHODS}

Chemicals and Solutions: Catechin, eriodictyol, apigenin, kaempferol and quercetin were from Extrasynthèse (Genay, France). The 5,4'-dihydroxy-3,6,7,8-tetramethoxyflavone, 5,5'-dihydroxy-6,7,3',4'-tetramethoxyflavone and 5,3'dihydroxy-3,6,7,8,4'-pentamethoxyflavone were a purified form of Gardenia obtusifolia Roxb. and their chemical structures were elucidated according to their spectroscopic properties:

\section{5,4'-Dihydroxy-3,6,7,8-Tetramethoxyflavone (WP 279)}

Crystals: yellow needles from EtOH m.p. 226.2-226.6 ${ }^{\circ} \mathrm{C}$ (m.p. $\left.225-226^{\circ} \mathrm{C}[22]\right)$.

UV $\lambda_{\max }^{\mathrm{MeOH}} \mathrm{nm}(\log \varepsilon): 283$ (4.70), 343 (4.73).

FTIR $v_{\max }^{K B r} \mathrm{~cm}^{-1}$ :

3221 (O-H stretching), $1648(\mathrm{C}=\mathrm{O}$ stretching of conjugated ketone), 1612, 1575, 1547, 1509, 1481, 1371, 1288, 1211, 1207, 1178, 1047, 1004, 920.

${ }^{1} \mathrm{H}-\mathrm{NMR}$ (300 MHz, DMSO-d ) $^{2}$

$\delta 12.43(\mathrm{~s}, 1 \mathrm{H}, 5-\mathrm{OH}), 10.40$ (br s, 1H, 4'-OH), 7.94 $\left(\mathrm{AA}^{\prime} \mathrm{BB}^{\prime}, 2 \mathrm{H}, J_{2,3}^{\prime}{ }^{\prime} \mathrm{J}_{6,5}^{\prime \prime}=9.1 \mathrm{~Hz}, J_{2,6}^{\prime}{ }_{6}^{\prime}, \mathrm{J}_{6,2}^{\prime}{ }^{\prime}=2.4 \mathrm{~Hz}, \mathrm{H}-2^{\prime}\right.$ and $\left.\mathrm{H}-6{ }^{\prime}\right), 6.95\left(\mathrm{AA}^{\prime} \mathrm{BB}^{\prime}, 2 \mathrm{H}, J_{3,2}^{\prime}, \mathrm{J}_{5,6}^{\prime}=9.1 \mathrm{~Hz}, J_{3,5}^{\prime}{ }^{\prime}, J_{5,3}^{\prime}{ }^{\prime}=\right.$ $2.4 \mathrm{~Hz}, \mathrm{H}-3^{\prime}$ and $\left.\mathrm{H}_{-} 5^{\prime}\right), 3.99$ (s, 3H, 7- $\left.\mathrm{OCH}_{3}\right), 3.86(\mathrm{~s}, 3 \mathrm{H}, 8-$ $\left.\mathrm{OCH}_{3}\right), 3.79\left(\mathrm{~s}, 3 \mathrm{H}, 6-\mathrm{OCH}_{3}\right), 3.77\left(\mathrm{~s}, 3 \mathrm{H}, 3-\mathrm{OCH}_{3}\right)$.

${ }^{13} \mathrm{C}-\mathrm{NMR}\left(75 \mathrm{MHz}, \mathrm{DMSO}-\mathrm{d}_{6}\right)$ :

$\delta 178.65(\mathrm{C}-4), 160.55\left(\mathrm{C}-4^{\prime}\right), 156.30(\mathrm{C}-2), 152.39(\mathrm{C}-$ 7), 148.23 (C-5), 144.42 (C-9), 137.63 (C-3), 136.00 (C-6), $132.54(\mathrm{C}-8), 130.14\left(\mathrm{C}-2^{\prime}\right.$ and $\left.\mathrm{C}-6^{\prime}\right), 120.56\left(\mathrm{C}-1^{\prime}\right), 115.86$ $\left(\mathrm{C}-3^{\prime}\right.$ and $\left.\mathrm{C}-5^{\prime}\right), 106.83(\mathrm{C}-10), 61.85\left(8-\mathrm{OCH}_{3}\right), 61.48(7-$ $\left.\mathrm{OCH}_{3}\right), 60.60\left(6-\mathrm{OCH}_{3}\right), 59.67\left(3-\mathrm{OCH}_{3}\right)$.<smiles>Oc1cc(O)c2c(c1)OC(c1ccc(O)c(O)c1)C(O)C2</smiles>

Catechin<smiles>CCOC(=O)OCC</smiles><smiles>COc1c(OC)c(O)c2c(=O)c(OC)c(-c3ccc(O)cc3)oc2c1OC</smiles>

5,4'-dihydroxy-3,6,7,8-tetramethoxyflavone(WP279)<smiles>O=c1cc(-c2ccc(O)cc2)oc2cc(O)cc(O)c12</smiles><smiles>O=c1c(O)c(-c2ccc(O)cc2)oc2cc(O)cc(O)c12</smiles><smiles>COc1cc(-c2cc(=O)c3c(O)c(OC)c(OC)cc3o2)cc(O)c1OC</smiles>

5,5'-dihydroxy-6,7,3',4'-tetramethoxyflavone(WP280)<smiles>O=c1c(O)c(-c2ccc(O)c(O)c2)oc2cc(O)cc(O)c12</smiles><smiles>COc1ccc(-c2oc3c(OC)c(OC)c(OC)c(O)c3c(=O)c2OC)cc1O</smiles>

5,3'-dihydroxy-3,6,7,8,4'-pentramethoxyflavone(WP283)

Fig. (1). Chemical structure of Catechin, eriodictyol, apigenin, kaempferol, quercetin, 5,4'-dihydroxy-3,6,7,8-tetramethoxyflavone (WP 279), 5,5'-dihydroxy-6,7,3',4'-tetramethoxyflavone (WP 280) and 5,3'-dihydroxy-3,6,7,8,4'-pentamethoxyflavone (WP 283) 
EIMS $m / z$ (\% relative intensity):

$374\left(\mathrm{M}^{+}, 55\right), 359$ (100), $356(<1), 343$ (8), 341 (7), 331 (4), 315 (5), 301 (9), 273 (6), 245 (8), 226 (,1), 211 (17), 197 (3), $193(<1), 187$ (15), 183 (14), 172 (9), 158 (17), 148 (3), 149 (5), 145 (15), 134 (19), 121 (50), 105 (19), 93 (15), 77 (10), 69 (25), 53 (11).

\section{5,5'-Dihydroxy-6,7,3',4'-Tetramethoxyflavone (WP 280)}

Crystals : white needles from EtOH m.p. $218.6-219.3^{\circ} \mathrm{C}$ (m.p.219-221 ${ }^{\circ} \mathrm{C}$ [23], m.p. $216^{\circ} \mathrm{C}$ [24]).

$\mathrm{UV} \lambda_{\max }^{\mathrm{MeOH}} \mathrm{nm}(\log \varepsilon)$ :

278 (4.49), 331(4.62).

FTIR $v_{\max }^{\mathrm{CHCl}_{3}} \mathrm{~cm}^{-1}$ :

$\delta 3383$ (O-H stretching), 1659 ( $\mathrm{C}=\mathrm{O}$ stretching of conjugated ketone), 1591, 1495, 1460, 1426, 1364, 1285, 1230, $1203,1170,1127,1101,1016,828,714$.

${ }^{1} \mathrm{H}-\mathrm{NMR}\left(300 \mathrm{MHz}, \mathrm{DMSO}-\mathrm{d}_{6}\right)$ :

$\delta 12.8(\mathrm{~s}, 1 \mathrm{H}, 5-\mathrm{OH}), 9.65\left(\mathrm{~s}, 1 \mathrm{H}, 5^{\prime}-\mathrm{OH}\right), 7.18(\mathrm{~d}, \mathrm{~J}=1.9$ $\left.\mathrm{Hz}, 1 \mathrm{H}, \mathrm{H}-6^{\prime}\right), 7.15$ (d, 1H, J = $\left.1.9 \mathrm{~Hz}, \mathrm{H}-2^{\prime}\right), 6.92$ (s, 1H, H3), 6.88 (s, 1H, H-8), 3.91 (s, 3H, 7- $\left.\mathrm{OCH}_{3}\right), 3.87$ (s, 3H, 3'$\left.\mathrm{OCH}_{3}\right), 3.74\left(\mathrm{~s}, 3 \mathrm{H}, 4-\mathrm{OCH}_{3}\right), 3.72\left(\mathrm{~s}, 3 \mathrm{H}, 6-\mathrm{OCH}_{3}\right)$.

${ }^{13} \mathrm{C}-\mathrm{NMR}\left(75 \mathrm{MHz}, \mathrm{DMSO}-\mathrm{d}_{6}\right)$ :

$\delta 182.38(\mathrm{C}-4), 163.57(\mathrm{C}-2), 158.86(\mathrm{C}-7), 153.63(\mathrm{C}-3$ ',

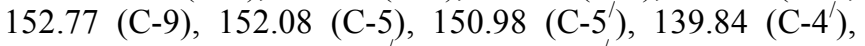
132.01 (C-6), 125.81 (C-1'), 107.90 (C-6), 105.27 (C-10), $104.52(\mathrm{C}-3), 102.21\left(\mathrm{C}-2^{\prime}\right), 91.68(\mathrm{C}-8), 60.22\left(4-\mathrm{OCH}_{3}\right)$, $60.13\left(6-\mathrm{OCH}_{3}\right), 56.54\left(7-\mathrm{OCH}_{3}\right), 56.26\left(3^{\prime}-\mathrm{OCH}_{3}\right)$.

EIMS $m / z$ (\% relative intensity):

$374\left(\mathrm{M}^{+}, 100\right), 359$ (71), 356 (2), 345 (18), 343 (13), 331 (13), 328 (15), 315(13), 299 (3), 298 (4), 273 (4), 181 (2), 181 (13), 179 (13), 164 (12), 153 (32), 135 (9), 121 (11), 69 (16).

\section{5,3'-Dihydroxy-3,6,7,8,4'-Pentamethoxyflavone (WP 283)}

Crystals: yellow needles from $\mathrm{EtOH}$, m.p. $171.6-172.2^{\circ} \mathrm{C}$ (m.p. $170^{\circ} \mathrm{C}$ [25], m.p. $169-170^{\circ} \mathrm{C}$ [26], m.p. $176-177^{\circ} \mathrm{C}$ [24]).

$$
\begin{aligned}
& \mathrm{UV} \lambda_{\max }^{\mathrm{MeOH}} \mathrm{nm}(\log \varepsilon) \text { : } \\
& 264(3.95), 282(3.97), 355(3.98) \\
& \text { FTIR } v_{\max }^{\mathrm{CHCl}_{3}} \mathrm{~cm}^{-1}:
\end{aligned}
$$

3546 (O-H stretching), 1647 ( $\mathrm{C}=\mathrm{O}$ stretching of conjugated ketone), 1596, 1561, 1512, 1481, 1463, 1376, 1275, 1249, 1249, 1135, 1052, 1006, 981.

\section{${ }^{1} \mathrm{H}-\mathrm{NMR}\left(300 \mathrm{MHz}, \mathrm{CDCl}_{3}\right)$ :}

$\delta 12.40(\mathrm{~s}, 1 \mathrm{H}, 5-\mathrm{OH}), 7.77\left(\mathrm{~d}, 1 \mathrm{H}, \mathrm{J}=2.0 \mathrm{~Hz}, 1 \mathrm{H}, \mathrm{H}-2^{\prime}\right)$, $7.76\left(\mathrm{dd}, 1 \mathrm{H}, \mathrm{J}=9.0\right.$ and $\left.2.0 \mathrm{~Hz}, \mathrm{H}-6^{\prime}\right), 6.98(\mathrm{~d}, 1 \mathrm{H}, \mathrm{J}=9.0$ $\left.\mathrm{Hz}, \mathrm{H}-5^{\prime}\right), 5.85$ (br s, $\left.1 \mathrm{H}, 3^{\prime}-\mathrm{OH}\right), 4.11$ (s, 3H, 7- $\left.\mathrm{OCH}_{3}\right), 3.98$ $\left(\mathrm{s}, 3 \mathrm{H}, 4^{\prime}-\mathrm{OCH}_{3}\right), 3.96\left(\mathrm{~s}, 3 \mathrm{H}, 6-\mathrm{OCH}_{3}\right), 3.95(\mathrm{~s}, 3 \mathrm{H}, 8-$ $\left.\mathrm{OCH}_{3}\right), 3.88\left(\mathrm{~s}, 3 \mathrm{H}, 3-\mathrm{OCH}_{3}\right)$.

${ }^{13} \mathrm{C}-\mathrm{NMR}\left(75 \mathrm{MHz}, \mathrm{CDCl}_{3}\right)$ :

$\delta 179.25(\mathrm{C}-4), 155.85$ (C-2), 152.80 (C-7), 149.03 (C5), $148.97\left(\mathrm{C}-4^{\prime}\right), 145.58\left(\mathrm{C}-3^{\prime}\right), 144.85$ (C-9), 138.76 (C-3),
136.00 (C-6), $132.80(\mathrm{C}-8), 123.46\left(\mathrm{C}^{\prime} 1^{\prime}\right), 121.50\left(\mathrm{C}-6^{\prime}\right)$, $\left.114.50\left(\mathrm{C}-2^{\prime}\right), 110.46\left(\mathrm{C}^{\prime}\right)^{\prime}\right), 107.39(\mathrm{C}-10), 62.06\left(6-\mathrm{OCH}_{3}\right)$, $61.63\left(7-\mathrm{OCH}_{3}\right), 61.07\left(8-\mathrm{OCH}_{3}\right), 60.03\left(3-\mathrm{OCH}_{3}\right), 55.97$ $\left(4^{\prime}-\mathrm{OCH}_{3}\right)$.

EIMS $m / z$ (\% relative intensity):

$404\left(\mathrm{M}^{+}, 66\right), 389$ (100), 386 (1), 373 (7), 361 (3), 359 (5), 345 (3), 331 (7), 303 (4), 275 (5), 271 (1), 259 (1), 229 (1), $226(<1), 211$ (11), 202 (8), 183 (11), 179 (3), 164 (9), 151 (21), 135 (12), 133 (3), 123 (7), 92 (7), 77 (10), 69 (23), 53 (14).

Prior to the commencement of the experiments stock solutions of each flavonoid $\left(10^{-2} \mathrm{M}\right)$ were freshly prepared in DMSO and then filtered through $0.22 \mu \mathrm{m}$ filter units (Chromos, Macclesfield, U.K.) before using. In order to avoid an auto-oxidation of molecules, the stock solutions were prepared under $\mathrm{N}_{2(\mathrm{~g})}$-saturated atmosphere.

All series of experiments were performed using HEPES/ $\mathrm{Na}^{+}$isotonic buffer solution, with varied $\mathrm{pH}$ at $37^{\circ} \mathrm{C}$, containing $20 \mathrm{mM}$ HEPES plus $132 \mathrm{mM} \mathrm{NaCl}, 3.5 \mathrm{mM} \mathrm{KCl}$, $1 \mathrm{mM} \mathrm{CaCl}_{2}, 0.5 \mathrm{mM} \mathrm{MgCl}_{2}$ and $5 \mathrm{mM}$ glucose.

\section{Spectrophotometric Measurements}

The absorption spectra were recorded on a Hewlett Packard HP 8435 and a Shimadzu, UV 2501 PC spectrophotometer. Experiments were conducted in a $1-\mathrm{cm}$ quartz cuvette containing $2 \mathrm{~mL}$ of solution under continuous stirring. The temperature was controlled at $37^{\circ} \mathrm{C}$ using a Peltier temperature control, cell holder model 89090A.

\section{Cell Culture and Cytotoxicity Assay}

Adriamycin-sensitive erythroleukemia cells (K562), adriamycin-resistant erythroleukemia cells (K562/adr, overexpressing P-gp), adriamycin-sensitive small cell lung carcinoma (GLC4) and adriamycin-resistant small cell lung carcinoma (GLC4/adr, overexpressing MRP1) were grown in RPMI-1640 medium supplemented with $10 \%$ fetal calf serum (Gibco Biocult Ltd.), in an incubator at $37^{\circ} \mathrm{C}, 95 \%$ humidified, $5 \% \mathrm{CO}_{2}[27,28]$. Cultures initiated at a density of $10^{5}$ cells $/ \mathrm{mL}$ grew exponentially to about $10^{6}$ cells $/ \mathrm{mL}$ in 3 days. K562/adr cell line was cultured in RPMI 1640 medium in the presence of $100 \mathrm{nM}$ doxorubicin for $72 \mathrm{~h}$, after that they were suspended in RPMI 1640 without doxorubicin medium for 2 weeks before the experiments. For the assays and in order to have cells in the exponential growth phase, cultures were initiated at $5 \times 10^{5}$ cells $/ \mathrm{mL}$ and used $24 \mathrm{~h}$ later after reaching a density of about $8 \times 10^{5}$ cells $/ \mathrm{mL}$.

The cytotoxicity assay was performed as follows: Cell $\left(5 \times 10^{4}\right.$ cells $\left./ \mathrm{mL}\right)$ was incubated in the presence of various concentrations of flavonoids tested. The viability of cells was determined by MTT reduction. The concentration of compound required for $50 \%$ inhibition of the proliferation of cells $\left(\mathrm{IC}_{50}\right)$ was determined by plotting the percentage of cell growth inhibition (\% IC) versus the compound concentration.

\section{Determination of Lipophilicity}

The partition coefficient of molecules ( $\log$ P) was determined in butanol- $\mathrm{Na}^{+}$-HEPES buffer system; both butanol and buffer fractions were analyzed by HPLC. The stock solutions $(10 \mu \mathrm{L})$ were added to the mixture of 1: 1 solution of butanol-HEPES-Na ${ }^{+}$buffer in a $2 \mathrm{~mL}$ tube to obtain the final 
concentration of $10^{-4} \mathrm{M}$ and were given vigorous mixing using a whirlimixer (Thermo Fisher Scientific Inc., England) for $1 \mathrm{~min}$. The tubes were centrifuged at $7000 \mathrm{rpm}$, allowing the two phases to separate. The butanol and buffer phases were separated and then lyophilized prior to HPLC analysis. Log $\mathrm{P}$ values were based on analysis of both aqueous and butanol fractions.

\section{HPLC Analysis}

Both the qualitative and quantitative analysis of flavonoids was performed with a high performance liquid chromatography (HPLC) Shimadzu (SPD-M20A photodiode Array detector, LC-20AD parallel type double plunger pump unit). Analytical RP-HPLC chromatography was performed on an Innertsil-ODS-3, $\mathrm{C}_{8}, 5 \mu \mathrm{m}$ particle size, 250 x $4.6 \mathrm{~mm}$ i.d. column (GL Sciences Inc.) protected with a guard column of the same material $\{20 \mathrm{~mm} \times 2.1 \mathrm{~mm}, 3 \mu \mathrm{m}$ packing (GL Sciences Inc.) $\}$. The solvent system was a gradient of solvent $\mathrm{A}$ (Water/HCl, $\mathrm{pH} 2.5$ ) and solvent $\mathrm{B}$ (acetonitrile): initial $0 \% \mathrm{~B}$, linear from 0 to $15 \%$ in $30 \mathrm{~min}, 15$ to 30 in $45 \mathrm{~min}, 30$ to $100 \%$ in $65 \mathrm{~min}$, isocratic with $100 \%$ for $20 \mathrm{~min}$, followed by washing and re-equilibrating the column. Flow rate was 1 $\mathrm{mL} \cdot \mathrm{min}^{-1}$.

\section{RESULTS}

\section{Spectrophotometric Determination of the Tautomeriza- tion of the Flavonoids}

Catechin in $\mathrm{Na}^{+}$-HEPES buffer solution possesses an absorption spectrum of between $250 \mathrm{~nm}$ to $300 \mathrm{~nm}$ with maximum absorbance at $278 \mathrm{~nm}$ identical to that dissolved in absolute ethanol (Fig. 2a). The absorption spectra of catechin did not change in the buffer solution of $\mathrm{pH}$ ranging from 2 to 8 . Spectral shape change was observed when the $\mathrm{pH}$ was comprised of 8 to 10 (Fig. 2a). The $\mathrm{pKa}$ value of catechin was equal to 8.6. Indeed, the tautomerization of flavonoids depends on a $\mathrm{C} 4=\mathrm{O}$ carbonyl group, especially the deprotonation of $\mathrm{C} 7-\mathrm{OH}$ is facilitated by the possibility for charge delocalization in the anion to the C4-keto moiety that is well characterized by spectrophotometry, particularly for eriodictyol as shown in Fig. (2b). In an acidic solution ( $\mathrm{pH} 3$ to 4), eriodictyol possesses an absorption spectrum between $250 \mathrm{~nm}$ to $425 \mathrm{~nm}$ with maximum absorbance at $286 \mathrm{~nm}$ identical to those in the ethanol phase. This indicates that the neutral form possesses one absorption band with the maximum absorbance at $286 \mathrm{~nm}$. The spectral shape of the absorption band changed in alkaline solutions; a decrease in the absorbance at $286 \mathrm{~nm}$ was observed, while a new absorption peak appeared with the maximum absorbance at $321 \mathrm{~nm}$ increasing with incremental $\mathrm{pH}$ values. The new absorption band corresponds to the tautomeric formation. The isobetic point was found at $300 \mathrm{~nm}$ signifying that in this solution there was equilibrium between the neutral and the cationic tautomeric form of eriodictyol. The $\mathrm{pKa}(\mathrm{C} 7-\mathrm{OH})$ of eriodictyol was equal to 7 .

Fig. (3a) provides the absorption spectra of apigenin in $\mathrm{Na}^{+}$-HEPES buffer with various $\mathrm{pH}$ and in absolute ethanol. Spectral shape of the absorption band of solutions $(\mathrm{pH} 1$ to 3) appeared between $250 \mathrm{~nm}$ to $425 \mathrm{~nm}$ with two peaks, one having the maximum absorbance at $330 \mathrm{~nm}$ identical to that of the molecule when dissolved in absolute ethanol and the other having the maximum absorbance at $409 \mathrm{~nm}$. It should be noted that apigenin in acidic solutions possesses a very low degree of light absorption but this increases when the $\mathrm{pH}$ is increased. Similar to catechin and eriodictyol, the absor- (a)

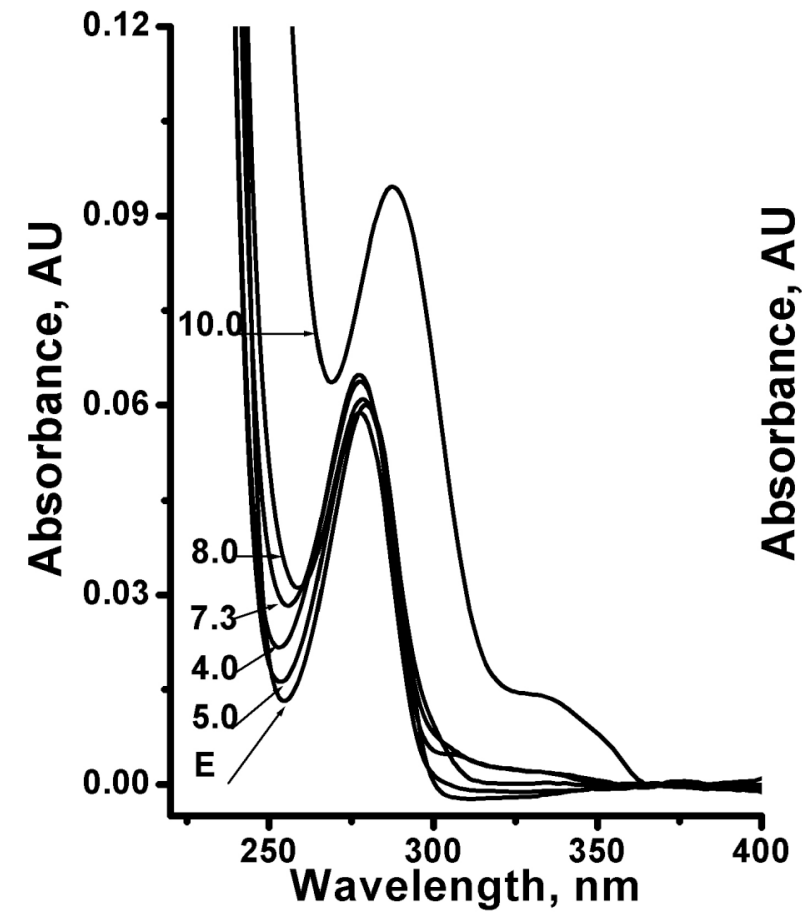

(b)

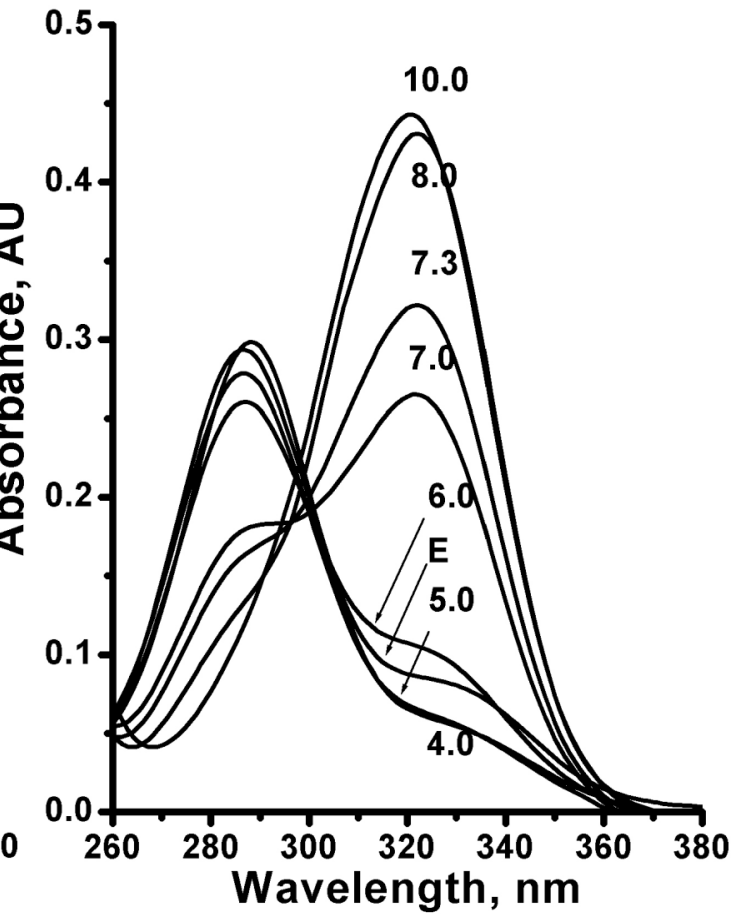

Fig. (2). Absorption spectra (a) catechin and (b) eriodictyol. The molecule $(10 \mu \mathrm{M})$ was dissolved in absolute ethanol (E) and in $\mathrm{Na}^{+}-\mathrm{HEPES}$ buffered with indicated $\mathrm{pH}$ values at $37^{\circ} \mathrm{C}$. 
bance at $330 \mathrm{~nm}$ of apigenin was increased about 3-fold in the presence of $50 \%$ (v/v of final volume) absolute ethanol. The results indicated that apigenin has very poor solubility properties. Only $10 \mu \mathrm{M}$ in aqueous solutions of $\mathrm{pH} 1$ to 3 was found in aggregate form, moreover the carybonyl group at $\mathrm{C} 4$ of ring $\mathrm{C}$ of the monomer form had undergone a nucleophilic substitution catalyzed by $\mathrm{H}_{3} \mathrm{O}^{+}$ions to form ketoenol tautomerization. Fig. (3b) demonstrates that the absorption bands of aqueous solutions of apigenin have a width at half the height of the spectrum, significantly larger than those in ethanol, the so-called compound spectrum. The absorption spectrum of solution $\mathrm{pH} 4$ at $37^{\circ} \mathrm{C}$ was mathematically deconvoluted and was found to compose of two absorption spectra; one has the maximal absorbance at $335 \mathrm{~nm}$ corresponding to the neutral form and the other band, the ionic form having the maximal absorbance at $390 \mathrm{~nm}$ (Fig. 3b). The $\mathrm{pKa}$ of $\mathrm{C} 7-\mathrm{OH}$ of apigenin was determined to be equal to 7.86 .

In acidic solutions with the $\mathrm{pH}$ ranging from 1 to 4 , kaempferol possesses an absorption spectrum identical to that of a molecule dissolved in absolute ethanol; the absorption band occurs between $250 \mathrm{~nm}$ to $450 \mathrm{~nm}$ with the maximum absorbance at $363 \mathrm{~nm}$ (Fig. 4a). It was clear that kaempferol was found in aggregation form in an acidic aqueous solution. When the $\mathrm{pH}$ of solutions was increased, the peak was shifted toward the red end of the spectrum. As indicated in Fig. (4b), at pH 7.3 kaempferol was equilibrated between neutral and ionic form. The absorption spectrum of solution $\mathrm{pH} 7.3$ was mathematically deconvoluted and can be classified into two absorption spectra, one corresponds to the neutral form and the other corresponds to the ionic form. Similar results were obtained for quercetin (Fig. 4c,d). The

(a)

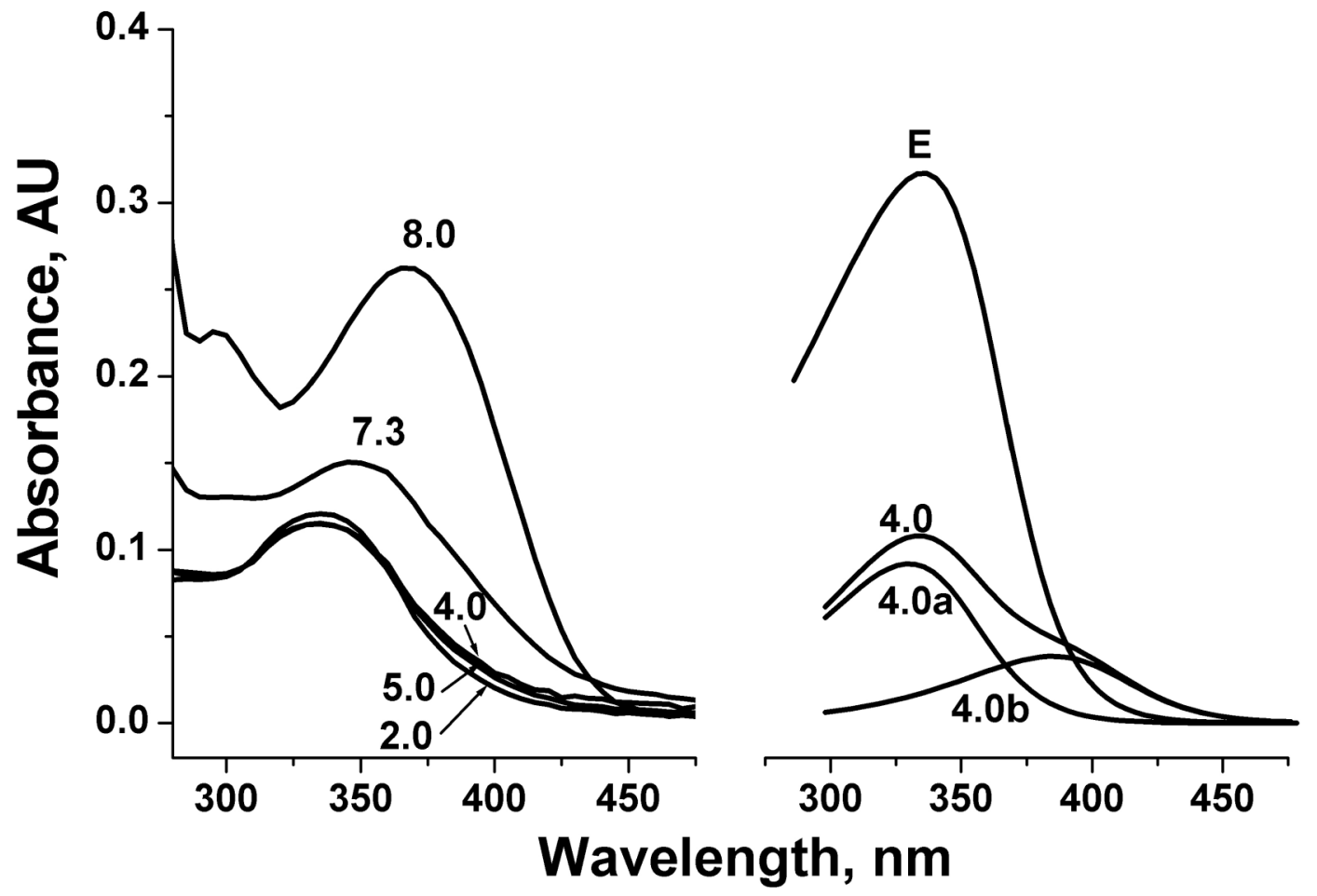

Fig. (3). Absorption spectra apigenin (a) in $\mathrm{Na}^{+}$-HEPES buffered with indicated $\mathrm{pH}$ values at $37^{\circ} \mathrm{C}$ and compound absorption spectra of solution of $\mathrm{pH} 4$ and its decomposed spectra compared with the absorption spectrum of molecule dissolved in absolute ethanol (E) (b).

$\mathrm{pKa}$ of $\mathrm{C} 7-\mathrm{OH}$ of kaempferol and quercetin were equal to 7.89 and 7.76, respectively. These results indicated that hydrogen bonding of the $\mathrm{C} 3-\mathrm{OH}$ or $\mathrm{C} 5-\mathrm{OH}$ with the $\mathrm{C} 4=\mathrm{O}$ group hampers deprotonation. Apigenin, kaempferol and quercetin have very poor solubility in aqueous solution, in the order: apigenin $>$ kaempferol $>$ quercetin.

In order to prevent any aggregate formation of these flavonoids, a series of flavonoids (WP 279, 280 and 283) were studied in which the methoxyl groups were substituted in place of hydroxyl groups at various carbon atoms of the molecule. Similar to apigenin, kaempferol and quercetin, WP 280 the $6,7,3^{\prime}, 4^{\prime}$ tetramethoxyl group substitution (see Fig. (1) for chemical structure) has very poor solubility in $\mathrm{Na}^{+}$HEPES buffer solution. It possesses an absorption spectrum between $250 \mathrm{~nm}$ to $350 \mathrm{~nm}$ with maximum absorbance at $345 \mathrm{~nm}$ (Fig. 5a). The nucleophilic substitution which was catalyzed by $\mathrm{H}_{3} \mathrm{O}^{+}$ions to form keto-enol tautomerization was still observed. The pKa cannot be spectrophotometrically determined for this molecule. It should be noted that the tautomerization via nucleophilic substitution which were catalyzed by $\mathrm{H}_{3} \mathrm{O}^{+}$ions to form keto-enol tautomeric form was not observed for WP 279 and WP 283 while the deprotonation at $\mathrm{C}^{\prime}$ '-OH (WP 279) or C3' (WP 283) following the tautomeric formation was observed in alkaline solutions. The pKa of WP 279 at $\mathrm{C}^{\prime}{ }^{\prime}-\mathrm{OH}$ and of WP 283 at C3'-OH was equal to 7.7 and 9.9 , respectively.

\section{Determination of Log P Values}

Lipophilicity is a major determinant of pharmacokinetic and pharmacodynamic properties of molecules involved in the same intermolecular forces as those acting in the partitioning of a solute between water and an immiscible organic phase.

\section{(b)}


(a)

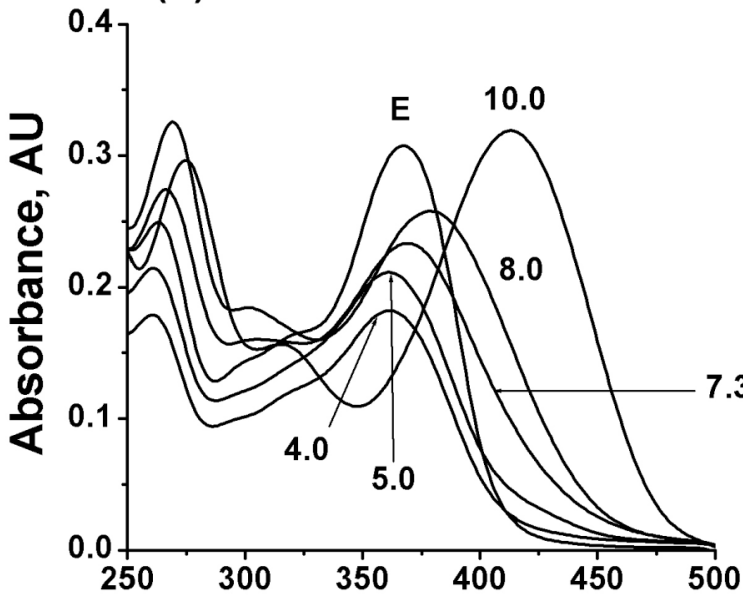

(c)

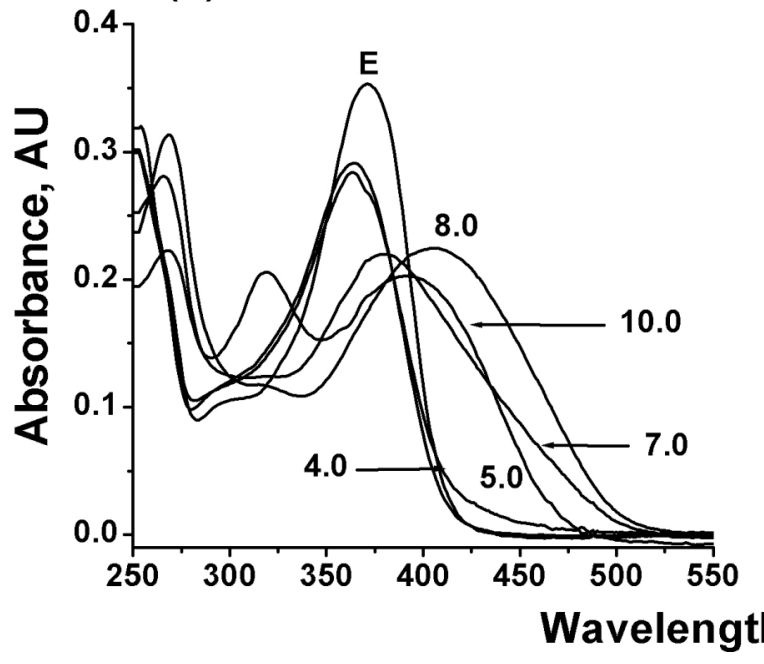

(b)

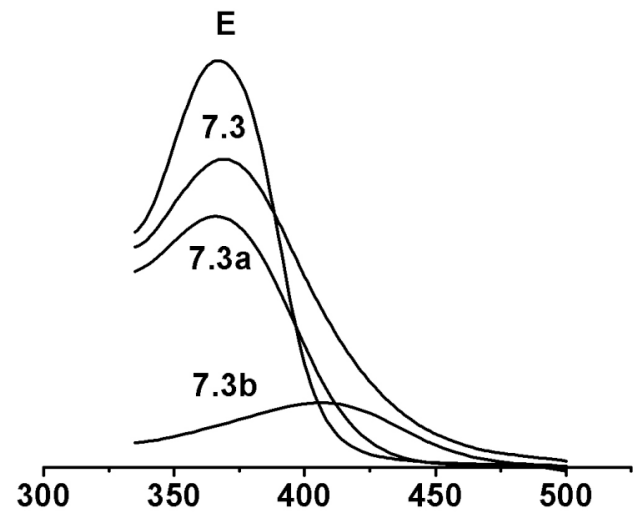

(d)

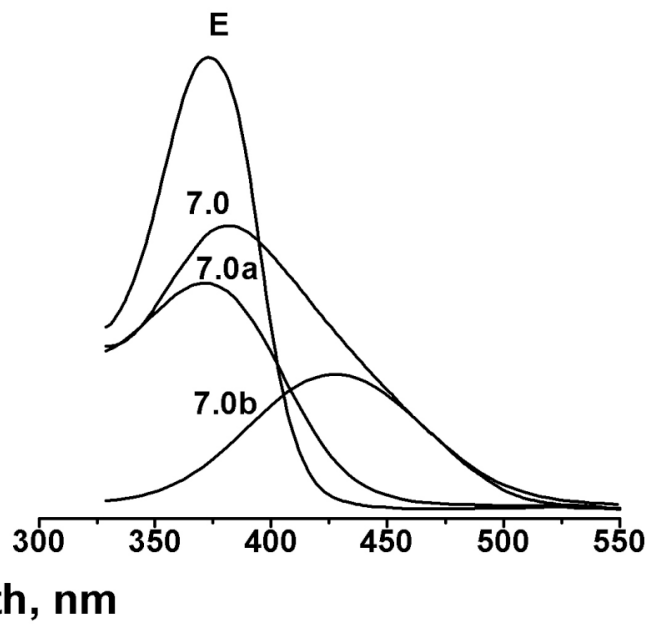

Fig. (4). Absorption spectra kaempferol (a), quercetin (c) in $\mathrm{Na}^{+}$-HEPES buffered with indicated pH values at $37^{\circ} \mathrm{C}$, and the compound absorption spectra of kaempferol (b) and quercetin (d).

Log $\mathrm{P}$ values are determined for the partitioning of a compound between water and octanol. In fact the molecules used in this study were found only in the octanol phase which somewhat limited our experiments. For these reasons, the logarithm of the butanol/ HEPES-Na ${ }^{+}$buffer partition coefficient, $\log \mathrm{P}$ of flavonoids was determined as indicated in the Table 1. Log P values of these molecules varied from $0.38 \pm$ 0.04 to $1.76 \pm 0.07$.

Considering the chemical structures; the series of flavonoids are very similar in chemical structure by different in substitutions of H-atom and/or hydroxyl group and/or methoxyl group at various carbon positions of flavonoid nucleus (Fig. 6). This is a very good set of data demonstrating that the substitutions affected a quantitative descriptor of the combined solute and solvent enthalpic and entropic physical interactions. By using apigenin as the reference compound, the Log P value of a given molecule can be expressed as follows:

$$
\log P=\log P_{(\text {Apigenin })}+\sum_{i=1}^{n}\left(\Delta \log P_{i}\right)_{\text {ringB }}+\sum_{i=1}^{n}\left(\Delta \log P_{i}\right)_{\text {ring } C}
$$

where $i$ is a number of substitution of the functional group on ring $\mathrm{B}$ and $\mathrm{C} . \Delta \log \mathrm{P}$ is the $\log \mathrm{P}$ difference between the considered molecule and that of apigenin. The calculated Log P values are very similar to the $\log \mathrm{P}$ determined from our experiments (Fig. 7) ( $\mathrm{r}^{2}$ of 0.998).

\section{Cytotoxicity of Flavonoids}

The flavonoids used in this study exhibited anticancer activity in a micro-molar concentration range, slightly more efficacy in MDR cells than their corresponding sensitive cell lines (Table 2). Apigenin exhibited a similar degree of anticancer activity against leukemic $\mathrm{K} 562\left(\mathrm{IC}_{50}=9.0 \pm 5.0 \mu \mathrm{M}\right)$, small cell lung carcinoma GLC4 $\left(\mathrm{IC}_{50}=4 \pm 2 \mu \mathrm{M}\right)$, and their corresponding multidrug resistant $\mathrm{K} 562 / \mathrm{adr}\left(\mathrm{IC}_{50}=9.0 \pm 3.0\right.$ $\mu \mathrm{M})$ and $\mathrm{GLC} 4 / \mathrm{adr}\left(\mathrm{IC}_{50}=6.0 \pm 0.5 \mu \mathrm{M}\right)$, cell lines. However, the efficacy of molecules did not change when the molecules contained $\mathrm{C} 2=\mathrm{C} 3, \mathrm{C} 4=\mathrm{O}$ and $\mathrm{C} 3-\mathrm{OH}$ (kaempferol and quercetin). This anticancer activity did not change except for a dramatic decrease against the multidrug resistant $\mathrm{K} 562 / a d r$ with overexpression of P-gp $\left(\mathrm{IC}_{50}>100 \mu \mathrm{M}\right)$, when the molecule lacks in $\mathrm{C} 2=\mathrm{C} 3$ (eriodictyol) and dramatically decreased against $\mathrm{K} 562\left(\mathrm{IC}_{50}>100 \mu \mathrm{M}\right)$, when the molecule lacks in both $\mathrm{C} 2=\mathrm{C} 3$ and $\mathrm{C} 4=\mathrm{O}$ (catechin).

All molecules of the series of methoxyl substitutions were found to have considerable increase in cytotoxicity against the 4 cell lines with similar efficacy in both drug- 
(a)

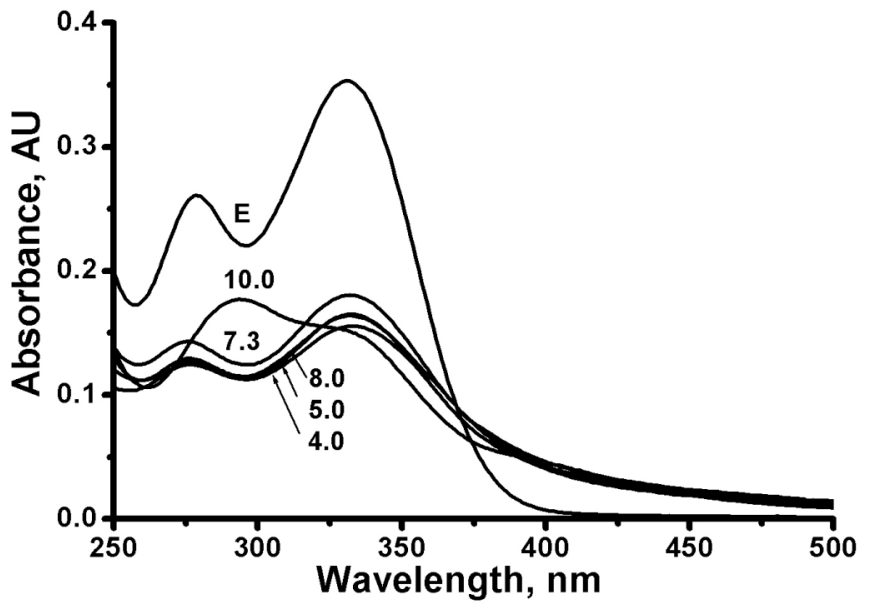

(b)

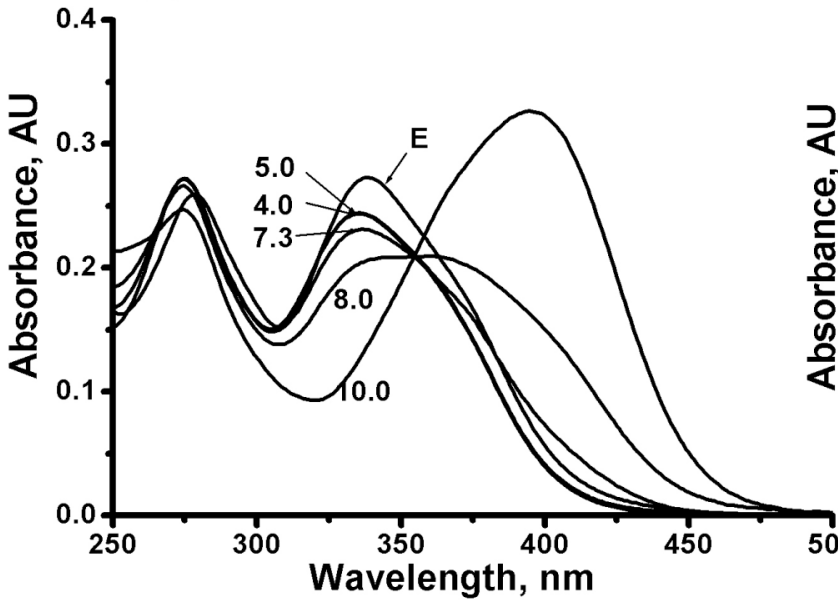

(c)

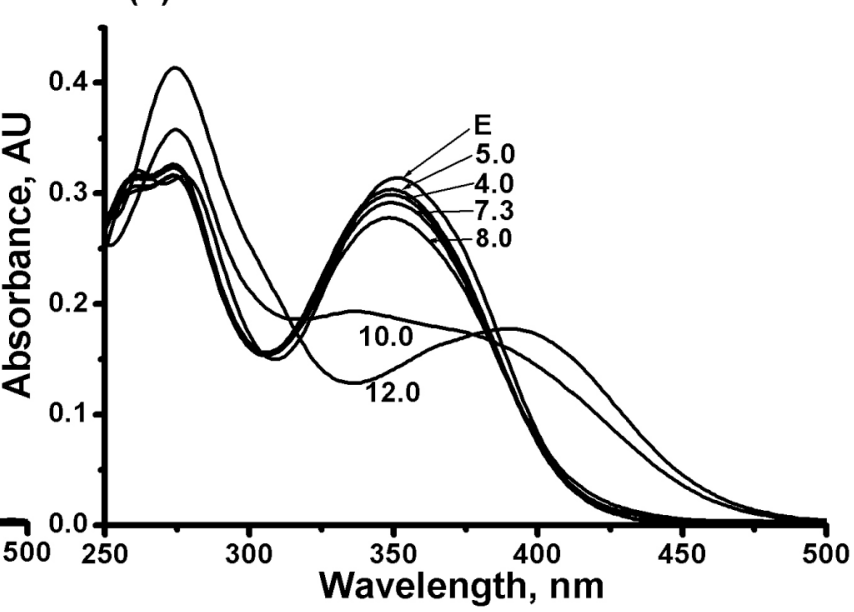

Fig. (5). Absorption spectra of WP 280 (a), WP 279 (b), and WP 283 (c) in $\mathrm{Na}^{+}$-HEPES buffered with indicated $\mathrm{pH}$ values at $37^{\circ} \mathrm{C}$ compared with the absorption spectrum of a molecule dissolved in absolute ethanol (E).

sensitive and drug-resistant cells. WP 280 exhibited about 5fold more efficacy than apigenin. It should be noted that among flavonoids studied, WP279 and WP 283 were the most potent anticancer molecules, particularly WP 283 in which the $\mathrm{IC}_{50}$ is in the nano-molar range of concentration $\left(\mathrm{IC}_{50}\right.$ value equal to $\left.150 \pm 50 \mathrm{nM}\right)$ that means about 60 -fold more potency than apigenin.

Table 1. Log P Values, Ionisation Rate Constants (pKa) and Neutral Form (\%) of Flavonoids in a $\mathrm{Na}^{+}$-HEPES Buffer at pH 7.25

\begin{tabular}{|l|c|c|c|}
\hline \multicolumn{1}{|c|}{ Molecules } & $\log \mathbf{P}$ & $\mathbf{p K a}$ & $\mathbf{D}^{\mathbf{0}} \mathbf{H}$ \\
\hline \hline Catechin & $0.38 \pm 0.04$ & 8.6 & 97.55 \\
\hline Eriodictyol & $1.40 \pm 0.05$ & 7.00 & 31.00 \\
\hline Quercetin & $1.47 \pm 0.16$ & 7.76 & 74.25 \\
\hline Apigenin & $1.50 \pm 0.17$ & 7.86 & 78.40 \\
\hline Kaempferol & $1.55 \pm 0.09$ & 7.89 & 79.55 \\
\hline WP279 & $1.57 \pm 0.02$ & 7.70 & 71.53 \\
\hline WP280 & $1.40 \pm 0.25$ & - & 100.00 \\
\hline WP283 & $1.76 \pm 0.07$ & 9.90 & 99.80 \\
\hline
\end{tabular}

\section{DISCUSSION}

This study demonstrates for the first time that the behavior of flavonoids in physiological solution is a predominant parameter determining their anticancer efficiency which was clearly measured by using a spectrophotometer. In fact the spectrophotometric study of chemical evolutions of flavonoids in a physiological solution is very simple and sensitive. For example, these flavonoids (only $10 \mu \mathrm{M}$ ) in $\mathrm{Na}^{+}$-HEPES at $\mathrm{pH} 4$ dramatically possesses a decrease in light absorption but this increases in the presence of $50 \%(\mathrm{v} / \mathrm{v}$ of final volume) absolute ethanol particular for apigenin, kaempferol and quercetin. The results signify that in $\mathrm{Na}^{+}$-HEPES at $\mathrm{pH} 4$ the molecules are major in aggregate form. The spectrophotometric measurements can also demonstrate the deprotonation and the tautomerization of flavonoids in physiological solution. This was done in order to obtain better knowledge of the factors determining the anticancer activity of these compounds.

The spectrophotometrically determined ionization constants of these flavonoids are macroscopic constants. Let's consider catechin, an $\mathrm{OH}$ group of the pyrone ring may not undergo deprotonation due to the very weak acidity of aliphatic alcohols [29]. The A- and B-rings of these compounds 
<smiles>[R4]c1ccc(-c2oc3cc(O)cc(O)c3c(=O)c2[R3])cc1[R4]</smiles>

\begin{tabular}{|c|c|c|}
\hline Position & Functional group & $\Delta \log F$ \\
\hline $\mathrm{C} 2, \mathrm{C} 3$ & $\begin{array}{l}\text { Double bond } \\
\text { Single bond }\end{array}$ & $\begin{array}{l}0 \\
-0.1\end{array}$ \\
\hline C4 & $\begin{array}{l}\mathrm{C} 4=\mathrm{O} \\
\mathrm{H}\end{array}$ & $\begin{array}{l}0 \\
-1.09\end{array}$ \\
\hline R3 & $\begin{array}{l}\mathrm{H} \\
\mathrm{OH} \\
\mathrm{OCH}_{3}\end{array}$ & $\begin{array}{l}0 \\
+0.05 \\
+0.07\end{array}$ \\
\hline R3' & $\begin{array}{l}\mathrm{H} \\
\mathrm{OH} \\
\mathrm{OCH}_{3}\end{array}$ & $\begin{array}{l}0 \\
-0.08 \\
-0.17\end{array}$ \\
\hline R4' & $\mathrm{OH}_{\mathrm{OCH}_{3}}$ & $\begin{array}{l}0 \\
+0.19\end{array}$ \\
\hline
\end{tabular}

Fig. (6). Chemical structure of flavonoid nucleus indicating different functional group substitutions and its $\log \mathrm{P}$ difference.

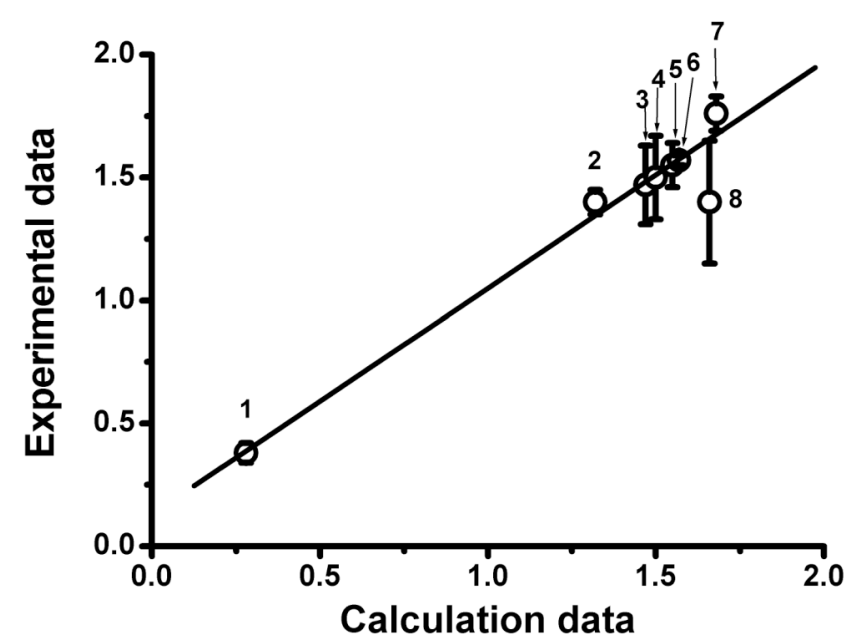

Fig. (7). Relationship between the experimental and calculated log $P$ values; 1, 2, 3, 4, 5, 6, 7 and 8 stand for catechin, eriodictyol, quercetin, apigenin, kaempferol, WP279, WP283 and WP 280, respectively. Line is linear least-square fit with $\mathrm{R}^{2}$ equal to 0.998 . The results were obtained from HPLC experiments and calculated using the expression:

$\log P=\log P_{(\text {Apigenin })}+\sum_{i=1}^{n}\left(\Delta \log P_{i}\right)_{\text {ring } B}+\sum_{i=1}^{n}\left(\Delta \log P_{i}\right)_{\text {ring } C} \quad$ as mentioned in results section.
Table 2. Cytotoxicity of flavonoids Against Small Cell Lung Carcinoma Drug-Sensitive GLC4 and DrugResistant GLC4/adr with Overexpression of MRP1 and Erythromyelogenous Leucemic Drug-Sensitive K562 and Drug-Resistant K562/adr with Overexpression of P-Glycoprotein $\left(\mathrm{IC}_{50}\right.$ is the Concentration of Molecule Requires to Inhibit Cancer Cells by $\mathbf{5 0 \% )}$

\begin{tabular}{|c|c|c|c|c|}
\hline \multirow{2}{*}{ Molecules } & \multicolumn{4}{|c|}{$\mathbf{I C}_{\mathbf{5 0}}, \boldsymbol{\mu} \mathbf{M}$} \\
\cline { 2 - 5 } & GLC4 & GLC4/R & $\mathbf{K 5 6 2}$ & $\mathbf{K 5 6 2 / R}$ \\
\hline \hline Catechin & $8.0 \pm 3.0$ & 10.0 & $>100$ & 4.6 \\
\hline Eriodictyol & $10.0 \pm 3.0$ & $10 \pm 2.5$ & $9.0 \pm 2.5$ & $>100$ \\
\hline Apigenin & $4 \pm 2.0$ & $6.0 \pm 0.4$ & $9.0 \pm 5$ & $9.0 \pm 3.2$ \\
\hline Quercetin & 6.0 & 11.5 & $6.0 \pm 1.4$ & $7.8 \pm 0.4$ \\
\hline Kaempferol & $6.5 \pm 0.7$ & $16.8 \pm 9.6$ & 8.5 & 7.0 \\
\hline WP279 & 0.5 & 0.7 & 0.8 & 0.8 \\
\hline WP280 & $1.1 \pm 0.6$ & $1.0 \pm 0.7$ & $4.0 \pm 3.0$ & $1.0 \pm 0.1$ \\
\hline WP283 & $0.2 \pm 0.2$ & $0.1 \pm 0.1$ & $0.2 \pm 0.2$ & $0.1 \pm 0.1$ \\
\hline
\end{tabular}

are not conjugated and ionzation of $\mathrm{OH}$ groups of one ring system should not affect ionization of $\mathrm{OH}$ groups of another. Slabbert reported that the macroscopic constants of ionization of A- and B-rings of catechin were equal to 8.79 and 9.44 , respectively [30]. In this study, the spectrophotometrically determined $\mathrm{pKa}$ of catechin $\left(\mathrm{C} 7-\mathrm{OH} / \mathrm{C} 7-\mathrm{O}^{-}\right)$was equal to 8.6 and these results suggested that the deprotonation of A-ring affected the absorption spectral shape change, but not B-ring. It was also found that the $\mathrm{C} 7-\mathrm{OH}$ of eriodictyol, apigenin, kaempferol and quercetin can also be deprotonated in physiological solution. Compared to catechin, the substitution of $\mathrm{C} 4=\mathrm{O}$ dramatically decreased while the $\mathrm{C} 2=\mathrm{C} 3$ and the $\mathrm{C} 3-\mathrm{OH}$ increased in $\mathrm{pKa}$ values of molecules. The particular observation was that the $\mathrm{C} 2=\mathrm{C} 3$ promotes an aggregation of molecules that can be prevented by $\mathrm{C} 3$-methoxyl substitution. The deprotonation of hydroxyl moiety at $\mathrm{C} 7-\mathrm{OH}$ facilitated the possibilities for charge delocalization in the anion to the C4-keto moiety [19] resulting in a tautomeric formation which was easily characterized using a spectrophotometer. The $\mathrm{C} 7-\mathrm{OH}$ deprotonation was obviously determined using spectrophotometer for eriodictyol, apigenin, kaempferol and quercetin, signifying that the tautomerization needs $\mathrm{C} 4=\mathrm{O}$ and $\mathrm{C} 5-\mathrm{OH}$. This indicates that the spectral shape change of eriodictyol, apigenin, kaempferol, and quercetin was probably caused by the $\mathrm{C} 7-\mathrm{OH}$ deprotonation. The methoxyl group at $\mathrm{C} 3$ facilitates a deprotonation of $\mathrm{C}^{\prime}-\mathrm{OH}$ (WP $279, \mathrm{pKa}=7.7$ ) and increases ionization energy when substitutions were found in B-ring (WP 283, $\mathrm{pKa}=9.9$ ). The $6,7,3^{\prime}, 4^{\prime}$-tetramethoxyl groups substitution (WP 280) can eliminate the deprotonation while promoting an aggregation of molecules in a physiological solution. The spectral shape of WP 280 was changed in alkaline $\mathrm{pH}$ corresponding to the tautomeric formation. This suggested that the carbonyl group at $\mathrm{C} 4$ should undergo nucleophilic substitution which was catalyzed by $\mathrm{H}_{3} \mathrm{O}^{+}$ions to form keto-enol tautomerization in physiological solution. 
Compared to catechin, the substitution of carbonyl group at $\mathrm{C} 4$ and $\mathrm{C} 2=\mathrm{C} 3$ double bond of $\mathrm{C}$-ring resulted in a considerable increase while the $\mathrm{OH}$ group substitution at $\mathrm{C} 3$ resulted in a decrease in lipophilicity of molecules. The 3,6,7,8-tetramethoxyl group substituting WP 279 yielded an increase in molecular weight, thus its lipophilicity. However this can prevent the molecule from undergoing aggregation particular for WP283.

In a physiological solution at $\mathrm{pH} 7.3$, catechin $(10 \mu \mathrm{M})$ was partially found in aggregated form and $97.55 \%$ was found in neutral form. Catechin exhibited a lower degree of cytotoxicity than apigenin, with particularly very low efficacy against leukemic cells. Eriodictyol exhibited similar anticancer activity to catechin and the particular observation, eriodictyol $(10 \mu \mathrm{M}) 31.0 \%$, was found in monomer neutral form in physiological solution (Fig. 2b). The anticancer activity was ameliorated in the series of molecules which contained $\mathrm{C} 2=\mathrm{C} 3$ and $\mathrm{C} 4=\mathrm{O}$. Among flavonoids used in this study, apigenin, kaempferol, quercetin and WP 280 were not readily soluble in physiological solution. The following molecules (only $10 \mu \mathrm{M}$ ) were mainly found in aggregated form, in the order: apigenin $>$ WP $280>$ kaempferol $>$ quercetin. These results suggested that in an aqueous physiological solution, these molecules were at equilibrium between neutral and ionic form, and the neutral form tended to be aggregated following a precipitation, thus reducing the neutral form available to possess anticancer action. It should be noted that these molecules possess similar degrees of anticancer activity in drug-sensitive and drug-resistant cells. The results showed that apigenin, kaempferol and quercetin have similar efficacy to inhibit the cancer cell growth but WP 280 exhibited almost 5-fold more than the three compounds. For interpreting these results, we hypothesized that the monomer neutral form of flavonoids should be passively diffused through plasma membrane to reach at their intracellular targets. In fact we have previously reported that apigenin, kaempferol and quercetin mediated cytotoxicity at mitochondrial level triggering the apoptosis of cancer cells [6, 7]. The degree of cytotoxicity of these molecules should be dependent on the high concentration of molecules at the intracellular targets that are responsible for their specific action. The results suggested that the proportion of neutral form (monomer) and the $\log \mathrm{P}$ values of these flavonoids are predominant parameters determining the anticancer activity of the molecules.

The results also clearly showed that both WP 279 and WP 283 did not undergo aggregation in physiological solution and were found in neutral form at $\mathrm{pH} 7.3$ about $71.53 \%$ for WP 279 and $99.8 \%$ for WP 283. This resulted in a considerable increase in cytotoxicity of molecules, particularly in the case of WP 283.

The results of this study clearly demonstrated that the $\mathrm{C} 2=\mathrm{C} 3$ in the molecule promote an aggregation of molecules, which can be prevented by $\mathrm{C} 3$-methoxyl substitution. The double bond should serve as an electron donor [20]. The $\mathrm{C} 4=\mathrm{O}$ carbonyl underwent nucleophilic substitution which was catalyzed by $\mathrm{H}_{3} \mathrm{O}^{+}$ions to form keto-enol tautomerization in physiological solution and should be responsible for the anticancer activity. The predominant molecular parameters should be neutral form and the active sites for anticancer activity of molecules are found in ring $\mathrm{A}$ and $\mathrm{C}$, particular $\mathrm{C} 4=\mathrm{O}, \mathrm{C} 5-\mathrm{OH}$ and $\mathrm{C} 2=\mathrm{C} 3$.

\section{ACKNOWLEDGEMENTS}

Montree Tungjai thanks to Graduate School of Chiang Mai University and the Commission on Higher Education, Ministry of Education for his scholarship.

This work was financial supported by The Commission on Higher Education, Ministry of Education, the Royal Thai government and the Thailand Research Fund grant number RMU4980034.

\section{ABBREVIATIONS}

$$
\begin{aligned}
\text { P-gp = } & \text { P-glycoprotein } \\
\text { MRP1 = } & \text { Multidrug resistance associated protein } \\
\text { MTT = } & \text { Tetrazolium salt, 3-(4,5-dimethyl-2-thiazolyl)- } \\
& 2,5 \text {-diphenyl-2H-tetrazolium bromide } \\
\text { HEPES = } & \begin{array}{l}
\text { N-2-Hydroxyethylpiperazine-N'-2-ethane- } \\
\text { sulfonic acid }
\end{array}
\end{aligned}
$$

\section{REFERENCES}

[1] Dechsupa, S.; Kothan, S.; Vergote, J.; Leger, G.; Martineau, A.; Beranger, S.; Kosanlavit, R.; Moretti, J.L.; Mankhetkorn, S. Cancer Biol. Ther., 2007, 6, 56.

[2] Kris-Etherton, P.M.; Hecker, K.D.; Bonanome, A.; Coval, S.M.; Binkoski, A.E.; Hilpert, K.F.; Griel, A.E.; Etherton, T.D. Am. J. Med., 2002,113, 71.

[3] Wenzel, U.; Kuntz, S.; Brendel, M.D.; Daniel, H. Cancer Res., 2000, 60, 3823.

[4] Romero, A.P.; Ferruelo, A.; Luján, M.; Berenguer, A. Brit. J. Urol. Inter., 2002, 89, 950.

[5] Ferry, D.R.; Smith, A.; Malkhandi, J.; Fyfe, D.W.; deTakats, P.G.; Anderson, D.; Baker, J.; Kerr D.J. Clin. Cancer Res.1996, 2, 659.

[6] Psahoulia, F.H.; Moumtzi, S.; Roberts, M.L.; Sasazuki, T.; Shirasawa, S.; Pintzas, A. Carcinogenesis, 2007, 28, 1021.

[7] Wu, H.B.; Zhao, X.; Wei, Y.Q. Clin. Cancer Res., 2006, 12, 3193.

[8] Kothan, S. Ph.D. dissertation, Université de Paris Nord and University of Burapha, 2004

[9] Dechsupa, N.; Tungjai, M.; Suttana, W.; Martinea, A.; Beranger, S.; Prarom, V.; Kothan, S.; Gunphairoh, R.; Moretti, J.L.; Mankhetkorn, S. in Free radical \& Antioxidants in Health, Diseases and Radiation, Proceeding of the $3^{\text {rd }}$ Biennial Meeting of the Society for Free Radical Research - Asia - SFRR-Asia, Lonavala, India, January 8-11, 2007; LeLe R.D.; Devasagayam T.P.A.; Adhikari S.; Society for Radiation Research-India: Italy, 2007; p 21-29.

[10] Kothan, S.; Dechsupa, S.; Moretti, J.L.; Vergote. J.; Mankhetkorn, S. Can. J. Physiol. Pharm., 2004, 82, 1084.

[11] Yin, F.; Giuliano, A.E.; Van Herle, A.J. Anticancer Res., 1999, 19, 4297.

[12] Choi, J.A.; Kim, J.Y.; Lee, J.Y.; Kang, C.M.; Kwon, H.J.; Yoo, Y.D.; Kim, T.W.; Lee, Y.S.; Lee, S.J. Int. J. Oncol., 2001, 19, 837.

[13] Benavente-Garcia, O.; Castillo, J.; Del Baño, M.J.; Lorente, J. J. Agric. Food Chem., 2001, 49, 189.

[14] Tommasini, S.; Raneri, D.; Ficarra, R.; Calabro, M.L.; Stancanelli, R.; Ficarra, P. J. Pharmaceut.Biomed., 2004, 35, 379.

[15] Webb, M.R.; Ebeeler, S. Biochem. J., 2004, 384, 527.

[16] Ofer, M.; Wolffram, S.; Koggel, A.; Spahn-Langguth, H.; Langguth, P. Eur. J. Pharm. Sci., 2005, 25, 263.

[17] Gracin, S.; Rasmuson, Å.C. J. Chem. Eng. Data.2002, 47, 1379.

[18] Saidman, E.; Yurquina, A.; Rudyk, R.; Molina, M.A.A.; Ferretti, F.H. J. Mol. Struct. THEOCHEM, 2002, 585, 1.

[19] Lemańska, K.; Szymsiak, H.; Tyrakowska, B.; Zieliński, R.; Soffers, A.E.M.F.; Rietjiens, I.M.C.M. Free radical Bio. Med., 2001, 31,869 .

[20] Sauerwald, N.; Schwenk, M.; Polster, J.; Bengsch, E. Zeitschrift fur Naturforschung, 1998, 53, 315.

[21] Dangles, O.; Saito, N.; Brouillard, R.; J. Am. Chem. Soc., 1993 115,3125 . 
[22] Gunatilaka, A.A.L.; Sirimanne, S.R.; Sootheeswaran, S.; Sriyani, H.T.B. Flavonoids of Gardenia cramerii and G. fosbergii bud exudates. Phytochemistry, 1982, 21, 805.

[23] Wollenweber, E.; Stern, S.; Roitman, J.N.; Yatskievych, G. Phytochemistry, 1989, 28, 303.

[24] Kinoshita, T.; Firman, K. Phytochemistry, 1996, 42, 1207.

[25] Gupta, S.R.; Seshadri, T.R.; Sood, G.R. Phytochemistry, 1973, 12, 2539.
[26] Roitman, J.N.; James, L.F. Phytochemistry., 1985, 24, 835.

[27] Meesungnoen, J.; Jay-Gerin, J.P.; Mankhetkorn, S. Can. J. Physiol. Pharm., 2002, 80, 1054

[28] Reungpattahanapong, P.; Dechsupa, S.; Meesungnoen, J.; Loetchutinat C.; Mankhetkorn, S. J. Biochem. Bioph. Meth., 2003 57,1 .

[29] Ballinger, P.; Long, F. A. J. Am. Chem. Soc., 1960, 82, 795.

[30] Slabbert, N.P. Tetrahedron, 1977, 33, 821. 